Journal id: GMFW_A_443268

Corresponding author: Ricardo Calado

Title: The capacity of crab megalopae to autotomize body appendages and the consequences upon their feeding ability the price to pay to live another day 


\section{The capacity of crab megalopae to autotomize body appendages and the consequences upon their feeding ability - the price to pay to live another day}

Ricardo Calado $^{a *}$, Ainhoa O. Olaguer-Feliúb ${ }^{\mathrm{b}}$, Juan Ignacio González-Gordillo ${ }^{\mathrm{b}}$ and Henrique Queiroga ${ }^{\mathrm{a}}$

${ }^{a}$ Departamento de Biologia da Universidade de Aveiro, Centro de Estudos do Ambiente e do Mar (CESAM), Campus Universitário de Santiago, 3810-193 Aveiro, Portugal;

${ }^{b}$ CACYTMAR - Centro Andaluz de Ciência e Tecnologia Marinha, Campus Universitario de Puerto Real, Puerto Real, Cádiz, Spain

During the mass settlement events of brachyuran crabs, there is a significant chance of density-dependent injury in the megalopae (last larval stage) because cannibalism can occur by larger conspecifics. Laboratory observations revealed that the appendages that are more prone to injury are eyestalks, as well as first (P1) and fifth (P5) pereiopods. The ability of Carcinus maenas megalopae to autotomize these structures and the effect of such injuries in their feeding ability and metamorphosis were investigated. All tested specimens were able to autotomize one or both of their P1 and P5, but not their eyestalks. Megalopae missing a single P1, as well as one or both P5, were able to capture and ingest prey, as well as intact specimens. Megalopae with either P1 and P5 appendages or at least one damaged eyestalk failed to ingest sufficient food to reach the nutritional threshold required for successful metamorphose.

Keywords: autotomy; Carcinus maenas; feeding ability; megalopae

\section{Introduction}

The majority of the marine decapod crustaceans display life history strategies that involve pelagic larvae which ultimately develop into an adult-like benthic juvenile form (Anger 2001). Brachyuran crabs display a transitional larval stage between the pelagic habitat of their early planktonic larvae (zoeae) and the benthic habitat of adults - the megalopa (Figure 1). Crab megalopae commonly perform an ontogenetic migration from pelagic to benthic environments and significant morphological and behavioral changes take place at this particular larval stage (Queiroga and Blanton 2004).

The simultaneous use of pelagic and benthic habitats exposes megalopae to higher predation pressure, with their predators ranging from planktivorous fish (Christy and Morgan 1998) to older conspecifics (Moksnes et al. 1998). During mass settlement events, the potential for density-dependent injury exists among

\footnotetext{
*Corresponding author. Email: rjcalado@hotmail.com
} 


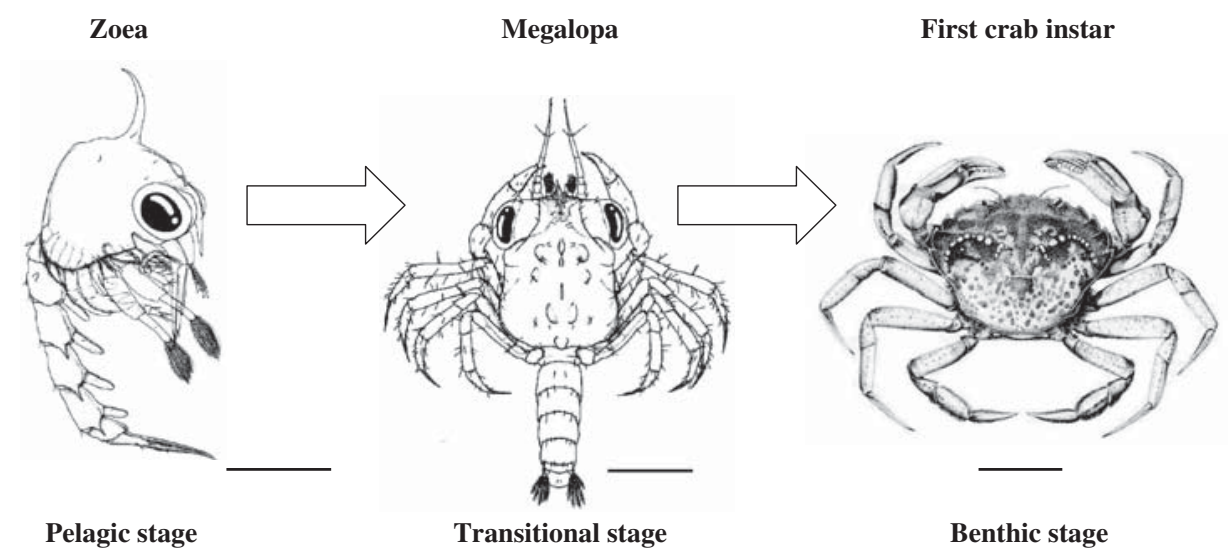

Figure 1. Different life stages of a brachyuran crab. Scale bars: $0.5 \mathrm{~mm}$.

megalopae, since cannibalism by larger conspecifics is known to occur (Moksnes et al. 1997, 1998). It is known that predatory attacks are not always successful and can cause non-lethal injuries (Vermeij 1982). When stocked under high densities in the laboratory (e.g., when simulating mass settlement events), the most commonly damaged appendages in megalopae are their first and fifth pereiopods (the first pereiopod is also termed cheliped or pincer), as well as their eyestalks (unpublished data). This damage is usually imposed by conspecifics before they metamorphose to the first crab instar (Figure 1). However, it is still unknown how significantly these variable types of non-lethal damage can interfere with the individual fitness of megalopae and their ability to metamorphose. The laboratory observations reported here appear to confirm the hypothesis proposed by Moksnes et al. (1998) that cannibalistic behavior could play a decisive role in the settlement dynamics of certain gregarious brachyuran crabs in nursery areas with variable habitat complexity.

The aim of the present work was to evaluate whether non-lethal injuries affect the feeding ability of crab megalopae, and to determine whether damaged specimens can still reach the nutritional threshold necessary for metamorphosis to the first crab instar. We also investigated whether crab megalopae have an innate ability to autotomize body appendages, namely their pereiopods, since autotomy is known to occur in juvenile and adult crabs as a primary response to escape from predators (Wood and Wood 1932; McVean 1982). In the present study, we define autotomy as an appendage loss without implying anything about the mechanisms involved (as proposed in the review by Maginnis 2006).

\section{Materials and methods}

\section{Sampling and stocking of crab megalopae}

The European shore crab Carcinus maenas (Linnaeus 1758) was selected as a model organism for the present work, since previous studies have already highlighted how young recruits of this species are exposed to a heavy predatory pressure, namely by cannibalistic juveniles (e.g., Moksnes et al. 1998). Carcinus maenas megalopae were 
collected at Costa Nova, Canal de Mira $\left(40^{\circ} 37^{\prime} \mathrm{N}, 8^{\circ} 44^{\prime} \mathrm{W}\right)$ in Ria de Aveiro (a mesotidal estuary in the west coast of Portugal) with passive plankton nets (described in detail by Queiroga et al. 2006). After isolation from other planktonic organisms sampled by the passive nets, the megalopae of $C$. maenas were stocked in a cooling chamber at $15^{\circ} \mathrm{C}$ inside $20 \mathrm{~L}$ cylindrico-spherical larviculture tanks (described by Calado et al. 2008). Only megalopae assumed to be on pre-moult stages 2 and 3 (according to the scale proposed by González-Gordillo et al. (2004); based on the general development of setagenesis and epidermal retraction from the integument) were selected for the experimental trials. This procedure was employed to assure a higher physiological homogeneity among experimental organisms, since specimens at different moult stages can display various feeding ability, energy partitioning, metabolism, and behavior (Anger 2001).

\section{Ability of crab megalopae to autotomize body parts and induction of non-lethal damage}

Although autotomy has already been recorded in juvenile and adult crabs (Juanes and Smith 1995), no study has ever confirmed the ability of crab megalopae to autotomize their pereiopods (including their chelipeds), or any other body part, as a potential escape response to predators. Thus, the following preliminary experiment was performed: a researcher would hold a cheliped, a fifth pereiopod or an eyestalk (as these are the body appendages commonly missing in megalopae mass cultured in captivity; see Figure 2 for a detailed location of targeted appendages) with a fine pair of forceps and monitor whether and after how long the megalopa would autotomize the targeted appendage. All 30 megalopae used in this trial were able to autotomize their chelipeds and fifth pereiopods in less than $3 \mathrm{~s}$ after being grasped by the forceps. Although all specimens struggled vigorously to free themselves from the forceps grasping their eyestalks, no specimen autotomized this appendage. A similar experiment was performed to evaluate the ability of megalopae that already had autotomized a single cheliped or fifth pereiopod to autotomize the remaining morphologically identical appendage. All 20 tested megalopae were able to autotomize the remaining cheliped or fifth pereiopod. Autotomized appendages detached from the larval body at the second limb segment, the basi-ischiopodite, by separating along a preformed breakage plane which encircles the segment. The existence of the breakage plane was confirmed by observing the region from which the autotomized appendage detached under a microscope.

From a physiological point of view, twisting and pulling a pereiopod is not comparable to autotomy, as it is significantly more stressful and promotes a prolonged physiological response (Patterson et al. 2007). After this preliminary experience, which confirmed the ability of crab megalopae to autotomize their chelipeds and fifth pereiopods (but not their eyestalks), the following approach was followed to induce non-lethal damage to megalopae used in the evaluation of their feeding motivation and ability: chelipeds and fifth pereiopods were removed from megalopae by inducing their autotomy (as described above); eyestalks were ablated immediately before their insertion in carapace with the help of sharp scissor like 110 pincers, in order to prevent the physiological damage commonly associated with eyestalk extirpation. This procedure aims to mimic predatory and/or cannibalistic 


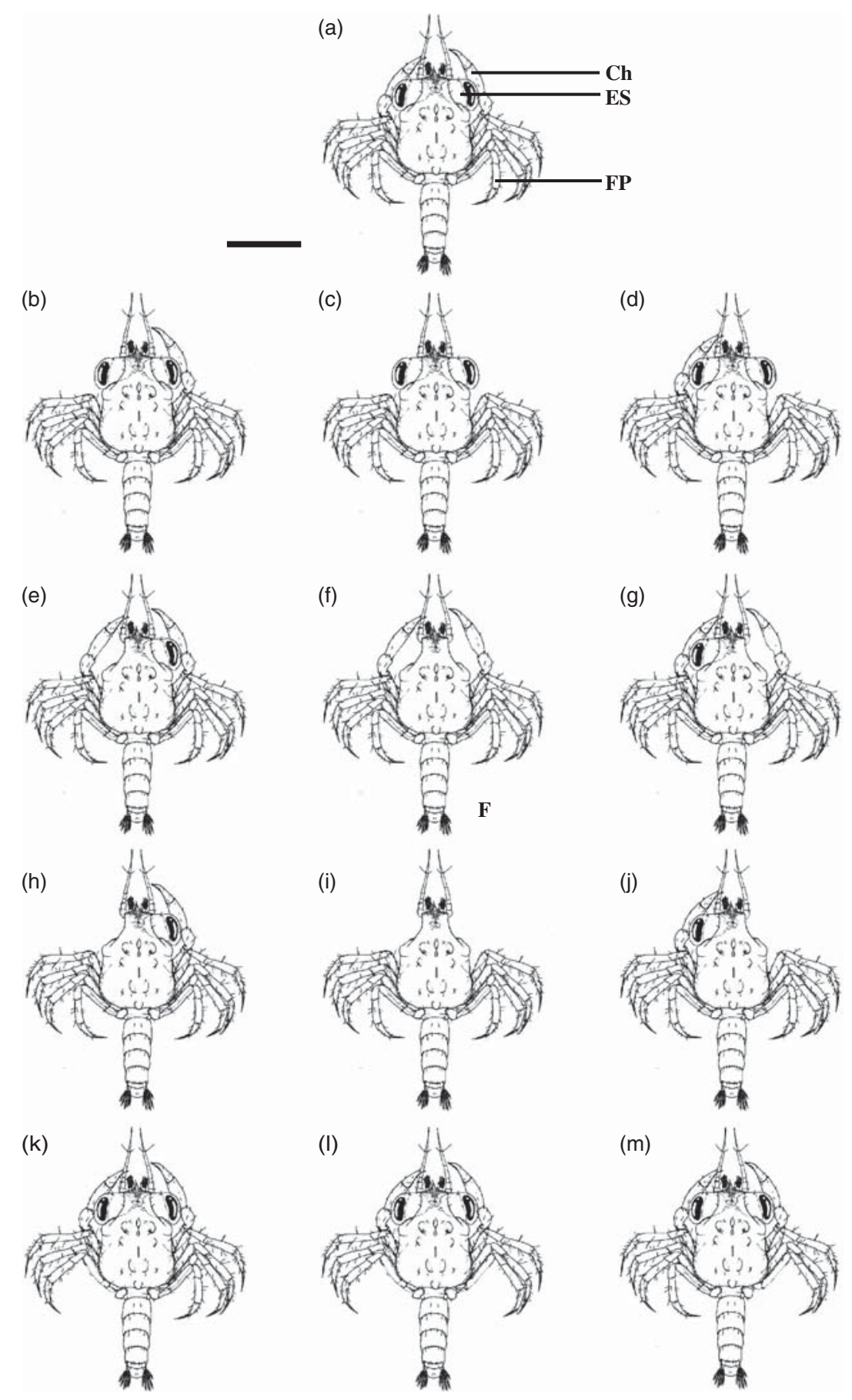

Figure 2. Different types of non-lethal damage inflicted to Carcinus maenas megalopae: A, intact; B, left cheliped autotomized; C, both chelipeds autotomized; D, right cheliped autotomized; E, left eyestalk ablated; F, both eyestalks ablated; G, right eyestalk ablated; $\mathrm{H}$, left eyestalk ablated and left cheliped autotomized; I, both eyestalks ablated and both chelipeds autotomized; J, right eyestalk ablated and right cheliped autotomized; K, left fifth pereiopod autotomized; L, both fifth pereiopods autotomized; M, right fifth pereiopod autotomized. Ch, cheliped; ES, eye stalk; FP, fifth pereiopod. Scale bar: $0.5 \mathrm{~mm}$. 
attacks in the field, and although it may appear to be fairly invasive and not self-reflexive, it is a biologically relevant and appropriate methodology.

\section{Effect of non-lethal damage on crab megalopae feeding motivation}

115 The feeding motivation of specimens that have been damaged can be suppressed by the stress associated with the removal of a given body part (even when it has been autotomized). On the other hand, it may be enhanced to produce extra energy to allow appendage regeneration. Both results ultimately affect their feeding ability. In this way, it is advisable to monitor the feeding motivation, before any experimental procedure, by supplying a food type easily consumed by damaged and intact specimens (Patterson et al. 2009). In the present study, we selected newly hatched Artemia nauplii as prey organisms due to their poor swimming ability and lack of anti-predatory defences (Dhont and Van Stappen 2003). A preliminary experiment was performed to evaluate whether damaged and intact specimens would react equally to dietary prey by placing five specimens from each group of "non-lethal damage type" (see Figure 2 for a detailed description; total number of tested megalopae $=5$ specimens $\times 13$ treatments $=65$ megalopae) in the presence of newly hatched Artemia nauplii. All specimens employed were starved for $24 \mathrm{~h}$ before experimentation. These preparations assured empty guts and a certain

130 homogenization of physiological status among intact and experimental specimens. Following the various types of non-lethal damage, each megalopa was placed in a small Petri dish $(52 \mathrm{~mm}$ diameter $)$ with $20 \mathrm{~mL}$ of natural seawater $(1 \mu \mathrm{m}$ filtered and UV irradiated) and fed 50 newly hatched Artemia nauplii $\left(2.5\right.$ nauplii $\left.\mathrm{mL}^{-1}\right)$.

Artemia cysts (Unibest ${ }^{\circledR}$ 020732) used in the present study to produce newly hatched nauplii were incubated and harvested according to Dhont and Van Stappen (2003).

All megalopae were observed individually under a stereomicroscope for $5 \mathrm{~m}$. Regardless of non-lethal damage type, all megalopae readily and similarly responded to the presence of Artemia nauplii in less than $5 \mathrm{~s}$, with observed specimens actively 140 swimming towards the prey and exhibiting the typical raptorial feeding behavior of brachyuran crab megalopae (for a detailed description, see McConaugha 2002). The feeding motivation of all observed megalopae remained similar during the observation period, with tested specimens chasing and ingesting Artemia nauplii.

\section{Effect of non-lethal damage on crab megalopae feeding ability and survival}

145 To estimate the effect of non-lethal damage on the feeding ability and survival of C. maenas megalopae, a total of 130 specimens were randomly selected and each individual was placed in a small Petri dish as described above. Megalopae were divided into 13 groups of 10 individuals and distributed among the following treatments: (1) intact specimens; (2) left cheliped autotomized; (3) both chelipeds autotomized; (4) right cheliped autotomized; (5) left eyestalk ablated; (6) both eyestalks ablated; (7) right eyestalk ablated; (8) left eyestalk ablated and left cheliped autotomized; (9) both eyestalks ablated and both chelipeds autotomized; (10) right eyestalk ablated and right cheliped autotomized; (11) left fifth pereiopod autotomized; (12) both fifth pereiopods autotomized; and (13) right fifth pereiopod autotomized (Figure 2). 
Once again, the rationale for using these types of non-lethal damage was based on the observation of the most common types of injuries displayed by crab megalopae mass cultured in the laboratory.

Damaged and intact megalopae were starved for $24 \mathrm{~h}$ (to assure empty guts) and each specimen was provided a total of 50 newly hatched Artemia nauplii as dietary prey $\left(2.5\right.$ nauplii $\left.\mathrm{mL}^{-1}\right)$. The larvae were kept in total darkness to ensure a homogeneous distribution of prey. The experimental room was kept at a constant temperature of $17 \pm 1^{\circ} \mathrm{C}$. The larvae were allowed to feed for $24 \mathrm{~h}$. After this feeding period, the number of live nauplii remaining in the Petri dish was counted under a binocular stereomicroscope.

\section{Feeding requirements of megalopae to metamorphose}

To evaluate the minimum number of newly hatched Artemia nauplii that need to be consumed daily by $C$. maenas megalopae to metamorphose successfully to the first crab instar, 90 specimens were randomly selected and each individual was placed in a small Petri dish as described above. Megalopae were divided into nine groups of 10 specimens and distributed among the following feeding treatments (total number of newly hatched Artemia nauplii per Petri dish): (1) 50 Artemia nauplii (2.5 nauplii $\left.\mathrm{mL}^{-1}\right)$; (2) 45 Artemia nauplii $\left(2.25\right.$ nauplii $\mathrm{mL}^{-1}$ ); (3) 40

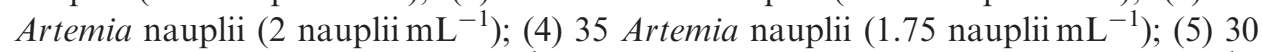
Artemia nauplii (1.5 nauplii $\left.\mathrm{mL}^{-1}\right)$; (6) 25 Artemia nauplii (1.25 nauplii $\left.\mathrm{mL}^{-1}\right)$; (7) 20 Artemia nauplii (1 nauplii $\left.\mathrm{mL}^{-1}\right)$; (8) 15 Artemia nauplii $\left(0.75\right.$ nauplii $\left.\mathrm{mL}^{-1}\right)$; and (9) 10 Artemia nauplii $\left(0.5\right.$ nauplii $\left.\mathrm{mL}^{-1}\right)$. Prior to the experiment, the megalopae were starved for $24 \mathrm{~h}$ to assure empty guts, and kept in total darkness in a climatized room at a constant temperature of $17 \pm 1^{\circ} \mathrm{C}$. Artemia nauplii and Petri dish seawater were renewed $100 \%$ every day. Each megalopae was kept under the experimental conditions, as previously described, until either successfully metamorphosing to the first crab instar or dying.

\section{Statistical analysis}

The effect of different types of non-lethal damage inflicted to C. maenas megalopae on their feeding ability was determined through one-way analysis of variance (ANOVA). The number of ingested prey was used as the dependent variable, while the non-lethal damage inflicted to each megalopae was used as the categorical factor. Statistical analyses were performed using the software Statistica version 6.0 (StatSoft Inc.), with the assumptions of normality and homogeneity of variance being verified prior to the analysis using the Shapiro-Wilks and Levene test, respectively. Whenever significance was accepted, at $p<0.05$, the Tukey multiple comparison test was used to perform a pairwise comparison of the means (Zar 1999).

\section{Ethical note}

No license was required to perform the present work, since decapod crustaceans (either larval or adult forms) are not covered by the Portuguese animal welfare guidelines. Autotomy does not promote the physiological stress response commonly recorded when simply pulling-off pereiopods from crabs (Patterson et al. 2007) and 
eyestalk ablation, as described in the present work, is less stressful than simple extirpation. Nevertheless, there is little doubt that these procedures are, at the very least, traumatic for targeted organisms. Nociception can be defined as the ability to detect a noxious stimulus and respond to it (Sneddon 2004), while pain can be defined as the unpleasant, emotional interpretation, or feeling associated with that perception (Broom 2007). Barr et al. (2008) and Elwood and Appel (2009) hypothesized that at least some decapod crustaceans may experience pain. Although no studies have ever confirmed whether the megalopae of brachyuran crabs can experience pain, we kept the number of specimens exposed to non-lethal damage to a minimum.

\section{Results}

\section{Effect of non-lethal damage on megalopae feeding ability}

210 The type of damage inflicted upon the megalopae significantly affected their ability to capture and ingest dietary prey $(\mathrm{df}=12, F=41.19 ; p<0.0001)$.

Intact megalopae consumed an average $( \pm \mathrm{SE})$ number of prey $(35.5 \pm 3.5)$ similar to those missing either one cheliped or one and both fifth pereiopods $(p>0.501)$. Megalopae missing both chelipeds ingested a significantly lower number of preys

215 than intact specimens $(24.4 \pm 3.0)(p<0.001$; Figure 3). Megalopae without chelipeds consumed an average number of Artemia nauplii similar $(p>0.871)$ to those missing one of their eyestalks $(22.3 \pm 5.7$ and $25.2 \pm 5.1$, for specimens with their right or left eyestalk ablated, respectively) and an eyestalk and a cheliped $(20.8 \pm 3.0$ and $22.2 \pm 2.5$, for specimens with their right or left eyestalk and cheliped

220 ablated, respectively), but significantly higher than that displayed by megalopae with both of their eyestalks ablated $(12.4 \pm 5.6, p<0.005)$. Megalopae missing both of their eyestalks and chelipeds ingested the lowest number of preys $(p<0.007)$, only consuming $3.6 \pm 1.2$ nauplii. There were no significant differences among the feeding ability of megalopae experiencing damage to the same appendage in the left or right side of their body (Figure 3).

\section{Feeding requirements of megalopae to metamorphose}

Only megalopae provided with at least 30 Artemia nauplii per day (prey density ranging from 1.5 to 2.5 prey $\mathrm{mL}^{-1}$ ) were able to successfully metamorphose to the first crab instar. The average duration of this last larval stage, until either metamorphosis or death, was significantly different $(\mathrm{df}=4, F=378.51 ; p<0.0001)$ among the experimental treatments. Megalopae that failed to metamorphose (those daily provided with only 25 Artemia nauplii, or less) displayed an average larval stage duration ( \pm standard error, SE) of $12.1 \pm 1.4$ days, while larvae successfully molting to the first crab instar remained in the larval stage of megalopa for only $6.5 \pm 0.9$ days.

\section{Discussion}

Decapod crustacean larvae are well known for their ability to delay metamorphosis in the presence of unsuitable nutritional conditions (Anger 2006). In order to advance to the first crab instar, megalopae must build up enough energetic reserves 


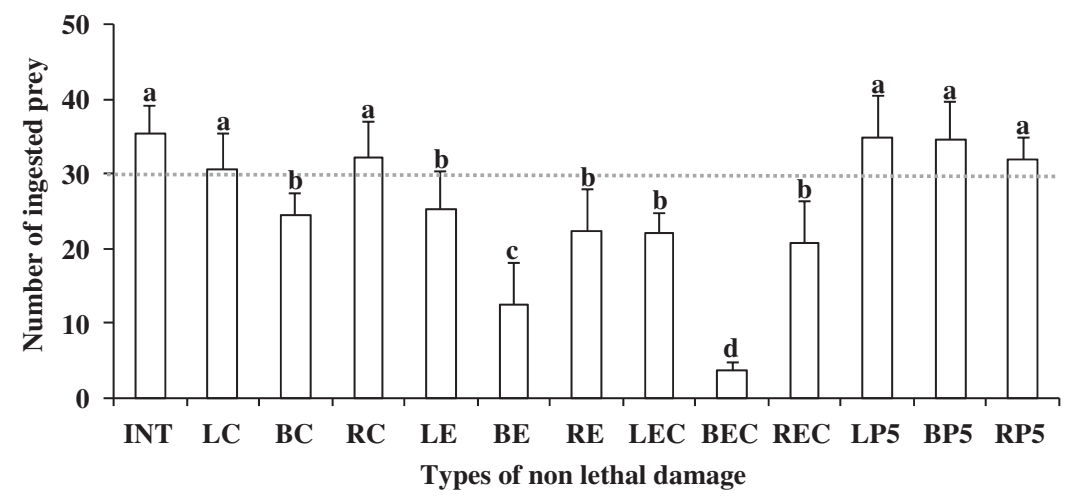

Figure 3. Average number ( \pm standard error) of Artemia nauplii consumed by C. maenas megalopae with different types of non-lethal damage: INT, intact; LC, left cheliped autotomized; $\mathrm{BC}$, both chelipeds autotomized; $\mathrm{RC}$, right cheliped autotomized; LE, left eyestalk ablated; BE, both eyestalks ablated; RE, right eyestalk ablated; LEC, left eyestalk ablated and left cheliped autotomized; BEC, both eyestalks ablated and both chelipeds autotomized; REC, right eyestalk ablated and right cheliped autotomized; LP5, left fifth pereiopod autotomized; BP5, both fifth pereiopods autotomized; RP5, right fifth pereiopod autotomized. The grey dotted line represents the minimum daily consumption of Artemia nauplii required for the megalopae to successfully metamorphose to the first crab instar. Different letters represent significant differences $(p<0.05)$.

prior to metamorphosis (Anger 2001). As C. maenas megalopae are planktotrophic, they must derive the energy from exogenous food sources until they have reached a nutritional threshold termed point of reserve saturation (PRS). According to Anger and Dawirs (1981), the PRS is a critical point within larval development beyond which food uptake is no longer essential for subsequent development and molting to the following larval stage, in the case of brachyuran crab megalopa, metamorphosis to the first crab instar. As recorded in the present work, the consumption of suboptimal food levels delays metamorphosis and significantly increases larval duration until the megalopa is able to reach the PRS. However, brachyuran megalopae are unable to delay metamorphosis indefinitely. If the nutritional requirements for metamorphosis are not fulfilled within a limited time frame, megalopae will invariably die without molting, as they are unable to become competent - receptive to settlement cues (Forward et al. 2001). Therefore, the significantly longer larval duration displayed in the present study when megalopae were fed a number of preys inferior to the minimum required to successfully metamorphose is a direct consequence of imposed nutritional stress. Similar levels of nutritional stress will also be experienced by megalopae, whose physical damage hinders the ingestion of adequate levels of prey (Figure 3). In this way, it is legitimate to assume that megalopae exhibiting certain types of non-lethal damage will also delay metamorphosis, since they will be able to capture and ingest a lower number of preys. If the number of ingested prey remains inferior to the minimum required to reach the nutritional threshold to allow metamorphosis, damaged specimens will continue to delay metamorphosis and will ultimately die.

Claw loss is a common feature among crustacean species in the wild (Juanes and Smith 1995; Mariappan et al. 2000). The present study revealed that brachyuran megalopae have the ability to autotomize some of their limbs (e.g., chelipeds and fifth pereiopods) just like the adult crabs. However, it is also evident that physical 
damage to different body parts of $C$. maenas megalopae significantly affects their feeding ability. Several brachyuran crabs respond to threats by outstretching their chelipeds, which increases their chances of surviving a predatory attack by anticipating it (Robinson et al. 1970; Jachowski 1974). This behavioral response was also recorded in the megalopae of $C$. maenas in the present work and confirmed that the anterior limbs of larvae may also be more prone to injury. Chelipeds are known to play a major role in prey capture by crab megalopae (McConaugha 2002). Megalopae with a single cheliped were still able to ingest a number of preys that would allow them to successfully reach metamorphosis.

Adult green crabs are known to display heterochely and handedness (Abby-Kalio and Warner 1989; Juanes et al. 2008). However, tested megalopae did not show any significant differences on their feeding ability when autotomizing either the right or left cheliped, which suggests that heterochely and handedness in C. maenas must only start to develop after metamorphosis.

When facing a predator, decapod crustaceans attempt to escape with the loss of, at most, a single limb (Juanes and Smith 1995). The results recorded in the present study suggest that crab megalopae may also display a similar strategy, at least concerning chelipeds damage. The loss of both chelipeds significantly decreased the ability of damaged megalopae to ingest dietary prey, a feature also recorded for adult crabs (Smith and Hines 1991). Nonetheless, megalopae withstanding this type of damage were still able to capture and ingest dietary prey through the compensatory use of their pereiopods (walking legs), as already recorded for adult crabs (Hiatt 1948; Smith and Hines 1991). Larvae without both chelipeds were not

290 able to ingest the minimum amount of Artemia nauplii required to successfully metamorphose. Chelipeds injury can lead to a shift to alternative prey in adult crabs (Edgar 1990), which may promote a reduction in energy accumulation, decrease growth increment and lengthened intermolt period duration (Skinner 1985; Juanes and Hartwick 1990). The use of planktonic and benthic habitat by megalopae implies plasticity in their feeding strategies, namely through the use of alternative feeding behaviors (raptorial and suspension feeding) (McConaugha 2002). Additionally, they are also able to ingest several different prey types, ranging from large microand meso-zooplankton to algae, heterotrophic dinoflagellates and detrital particles (e.g., Harms and Seeger 1989; Factor and Dexter 1993; Perez and Sulkin 2005;

300 Burnett and Sulkin 2007). However, laboratory trials revealed that larvae fed on diatoms, phytoplankton, and other small-sized food particles are rarely able to metamorphose (Harms and Seeger 1989; Harms et al. 1991; Harms 1992). In this way, if $C$. maenas megalopae missing both of their chelipeds are not able to predate large-sized (thus more energetic) zooplankton, they may not be able to reach the PRS 305 and metamorphose to the first crab instar. Nevertheless, it is important to highlight that if a megalopa loses both chelipeds after reaching the PRS, it will still be able to successfully metamorphose (unpublished data).

Although the loss of either one or both fifth pereiopods did not result in any major deleterious effect concerned with prey capture, it is unknown how ecologically

310 relevant these findings may be. According to Juanes and Smith (1995), surprise attacks from the rear often prove fatal to adult crabs. Following this rationale, it is legitimate to assume that the same scenario will also occur for crab megalopae. In this way, although it is common to record this type of damage in the mass culture laboratory trials, it is rare to record C. maenas megalopae or young juveniles in the wild missing their fifth pereiopod(s). 
Eyestalks shelter the major neuroendocrine centre of larval and adult decapod crustaceans, the X-organ-sinus-gland complex (Charmantier and CharmantierDaures 1998). Although it has been widely accepted that decapod crustaceans cannot regenerate their eyestalks (Hopkins 1988), recent evidences from penaeid prawns indicate that these organisms may indeed completely regenerate these organs in appearance, shape, size, structure, and pigmentation several months after ablation (Desai and Achuthankutty 2000). Nonetheless, these organs are commonly protected by a more or less robust eye socket, and any damage affecting the eyestalk is always likely to induce physiological stress. Therefore, although the loss of chelipeds seems to reduce larval ability to capture prey, eyestalk injuries appear to reduce prey ingestion by adversely affecting the physiological fitness of damaged individuals. The fact that all our trials were performed in absolute darkness demonstrates that this effect is not due to impaired eye sight. It is important to note that if eyestalk damage occurs after the megalopa has reached the PRS, not only will it be able to metamorphose, but the molt cycle will be abbreviated and the timing to metamorphosis will be anticipated (Snyder and Chang 1986). Due to the levels of physiological stress associated with the eyestalk damage and the "violence of the attack" required to damage these appendages "not designed to be left behind", C. maenas megalopae will probably never be recorded in the wild exhibiting this type of damage. A predator/conspecific capable of inflicting damage to the eyestalks of a megalopae will certainly also be able to effectively predate/cannibalize that specimen, as it will benefit from the lack of suitable evasive response by the prey (as displayed when autotomizing a cheliped) and from the physiological stress imposed by the attack.

340 It has already been documented in brachyuran crabs that reduced larval fitness may be "carried-over" metamorphosis into the benthic phase (Giménez, 2006), which can negatively affect the juvenile survival and growth (Giménez et al. 2004; Torres et al. 2008). Physical damage induced to megalopae can promote smaller body sizes of newly metamorphosed crabs (unpublished data). As reported by Juanes and Smith (1995), if smaller animals display lower foraging times to avoid predation, they are forced to abandon shelters to larger conspecifics and are unable to capture suitable prey, and the cumulative effects of non-lethal injuries can be significantly magnified. Additionally, a newly metamorphosed crab which had previously lost a cheliped, while in the megalopa stage, will be regenerating this appendage. This constraint will certainly reduce its foraging and antipredatory ability.

Non-lethal damage induced by unsuccessful predatory/cannibalistic attacks can significantly affect the ability of megalopae to metamorphose (or even be "carried-over" metamorphosis and negatively affect the fitness of young crabs) and it appears that there is indeed "a price to pay to live another day". In fact, "living another day" may just not be enough for some megalopae surviving agonistic interactions. "The price to pay" for escaping with "only" non-lethal damage is sometimes just too high for some specimens as they lose their ability to metamorphose and invariably end-up dying.

\section{Acknowledgments} megalopae of Carcinus maenas and Patricia Pochelon for her technical support. We also thank 
the anonymous reviewers for their valuable comments and suggestions on the initial manuscript.

\section{References}

Abby-Kalio NJ, Warner GF. 1989. Heterochely and handedness in the shore crab Carcinus maenas (L.) (Crustacea: Brachyura). Zool J Linn Soc. 96:19-26.

Anger K. 2001. The biology of decapod crustacean larvae - crustacean issues. Vol. 14. Rotterdam(Netherlands): A. A. Balkema Publishers.

Anger K. 2006. Contributions of larval biology to crustacean research: a review. Invertebr Repr Dev. 49:175-205.

Anger K, Dawirs R. 1981. Influence of starvation on the larval development of Hyas araneus (Decapoda, Majidae). Helgoländer Wiss. Meeresunters. 34:287-311.

Barr S, Laming P, Dick J, Elwood RW. 2008. Nociception or pain in a decapod crustacean? Anim Behav. 75:745-751.

Broom DM. 2007. Cognitive ability and sentience: which aquatic animals should be protected? Dis Aquat Org. 75:99-108.

Burnett B, Sulkin S. 2007. Characteristics of feeding on dinoflagellates by newly hatched larval crabs. Mar Biol. 151:851-861.

Calado R, Pimentel T, Vitorino A, Dionísio G, Dinis MT. 2008. Technical improvements of a rearing system for the culture of decapod crustacean larvae, with emphasis on marine ornamental species. Aquaculture. 285:264-269.

Charmantier G, Charmantier-Daures M. 1998. Endocrine and neuroendocrine regulations in embryos and larvae of crustaceans. Int J Invertebr Repr Dev. 33:273-287.

Christy JH, Morgan SG. 1998. Estuarine immigration by crab postlarvae: mechanisms, reliability and adaptive significance. Mar Ecol Progr Ser. 174:51-65.

Desai UM, Achuthankutty CT. 2000. Complete regeneration of ablated eyestalk in penaeid prawn. Penaeus monodon. Curr Sci. 79:1602-1603.

Dhont J, Van Stappen G. 2003. Biology, tank production and nutritional value of Artemia. In: Stottrup JG, McEvoy LA, editors. Live feeds in marine aquaculture. Oxford: Blackwell Science. p. 65-121.

Edgar GJ. 1990. Predator-prey interactions in seagrass beds. II. Distribution and diet of the blue manna crab Portunus pelagicus Linnaeus at Cliff Head, Western Australia. J Exp Mar Biol Ecol. 139:23-32.

Elwood RW, Appel M. 2009. Pain experience in hermit crabs? Anim Behav. 77:1243-1246.

Factor JR, Dexter BL. 1993. Suspension feeding in larval crabs (Carcinus maenas). J Mar Biol Assoc UK. 73:207-211.

Forward RB, Tankersley RA, Rittschof D. 2001. Cues for metamorphosis of brachyuran crabs: an overview. Amer Zool. 41:1108-1122.

Giménez L. 2006. Phenotypic links in complex life cycles: conclusions from studies with decapod crustaceans. Integr Comp Biol. 46:615-622.

Giménez L, Anger K, Torres G. 2004. Linking life history traits in successive phases of a complex life cycle: effects of larval biomass on early juvenile development in an estuarine crab. Chasmagnathus granulata. Oikos. 104:570-580.

González-Gordillo JI, Rodriguez A, Queiroga H. 2004. Characterization of the megalopal premoult stages of the green crab, Carcinus maenas (Decapoda, Portunidae), from laboratory culture. J Crust Biol. 24:502-510.

Harms J. 1992. Effects of nutrition (herbivore vs. carnivore) on energy charge and nucleotide composition in Hyas araneus. Helgolander Meeresun. 46:29-44.

Harms J, Anger K, Klaus S, Seeger B. 1991. Nutritional effects on ingestion rate, digestive enzyme activity, growth, and biochemical composition of Hyas araneus L. (Decapoda: Majidae) larvae. J Exp Mar Biol Ecol. 145:233-265. 
Harms J, Seeger B. 1989. Larval development and survival in seven decapod species (Crustacea) in relation to laboratory diet. J Exp Mar Biol Ecol. 133:129-139.

Hiatt RW. 1948. The biology of the lined shore crab, Pachygrapsus crassipes Randall. Pac Sci. 2:135-213.

Hopkins P. 1988. Control of regeneration in crustaceans. In: Endocrinology of selected invertebrate types. New York: AR Liss. p. 327-340.

Jachowski RL. 1974. Agonistic behavior of the blue crab, Callinectes sapidus Rathbun. Behaviour. 50:232-253.

Juanes F, Hartwick EB. 1990. Prey size selection in Dungeness crabs: the effect of claw damage. Ecology. 71:744-758.

Juanes F, Lee KT, McKnight A, Kellogg K. 2008. Claw allometry in green crabs, Carcinus maenas: heterochely, handedness, and sex. Mar Biol. 153:523-528.

Juanes F, Smith LD. 1995. The ecological consequences of limb loss and damage in decapod crustaceans: a review and prospectus. J Exp Mar Biol Ecol. 193:197-223.

Maginnis TL. 2006. The costs of autotomy and regeneration in animals: a review and framework for future research. Behav Ecol. 17:857-872.

Mariappan P, Balasundaram C, Schmitz B. 2000. Decapod crustacean chelipeds: an overview. J Biosci. 25:301-313.

430 McConaugha J. 2002. Alternative feeding mechanisms in megalopae of the blue crab Callinectes sapidus. Mar Biol. 140:1227-1233.

McVean A. 1982. Autotomy. In: Bliss D, editor. Vol. 4. The biology of crustacea. New York: Academic Press. p. 107-132.

Moksnes PO, Lipcius RN, Pihl L, van Montfrans J. 1997. Cannibal-prey dynamics in young juveniles and postlarvae of the blue crab. J Exp Mar Biol Ecol. 215:157-187.

Moksnes PO, Pihl L, van Montfrans J. 1998. Predation on postlarvae and juveniles of the shore crab Carcinus maenas: importance of shelter, size and cannibalism. Mar Ecol Progr Ser. 166:211-225.

Patterson L, Dick JTA, Elwood RW. 2007. Physiological stress responses in the edible crab, Cancer pagurus, to the fishery practice of de-clawing. Mar Biol. 152:265-272.

Patterson L, Dick JTA, Elwood RW. 2009. Claw removal and feeding ability in the edible crab, Cancer pagurus: implications for fishery practice. Appl Anim Behav Sci. 116:302-305.

Perez M, Sulkin S. 2005. Palatability of autotrophic dinoflagellates to newly hatched larval crabs. Mar Biol. 146:771-780.

Queiroga H, Almeida MJ, Alpuim T, Flores AAV, Francisco S, Gonzalez-Gordillo JI, Miranda AI, Silva I, Paula J. 2006. Wind and tide control of megalopae supply to estuarine crab populations on the Portuguese west coast. Mar Ecol Progr Ser. 307:21-36.

450 Queiroga H, Blanton JO. 2004. Interactions between behaviour and physical forcing in the control of horizontal transport of decapod crustacean larvae: an overview. Adv Mar Biol. 47:105-212.

Robinson MH, Abele AG, Robinson B. 1970. Attack autotomy: a defence against predators. Science. 169:300-301.

455 Skinner DM. 1985. Molting and regeneration. In: Bliss DE, Mantel LH, editors. Vol. 9. The biology of crustacea. New York: Academic Press. p. 43-146.

Smith LD, Hines AH. 1991. The effect of cheliped loss on blue crab Callinectes sapidus Rathbun foraging rate on soft-shelled clams Mya armaria L. J Exp Mar Biol Ecol. 151:245-256.

460 Sneddon L. 2004. Evolution of nociception in vertebrates: comparative analysis of lower vertebrates. Brain Res Rev. 46:123-130.

Snyder MJ, Chang ES. 1986. Effects of eyestalk ablation on larval molting rates and morphological development of the American lobster. Homarus americanus. Biol Bull. 170:232-243. 
465 Torres G, Giménez L, Anger K. 2008. Cumulative effects of low salinity on larval growth and proximate biochemical composition in an estuarine crab, Neohelice granulata. Aquatic Biol. 2:37-45.

Vermeij GJ. 1982. Unsuccessful predation and evolution. Amer Nat. 120:701-720.

Wood FD, Wood HE. 1932. Autotomy in decapod crustacea. J Exp Zool. 62:1-55.

470

Zar JH. 1999. Biostatistical analysis. 4th ed. Upper Saddle River, NJ: Prentice Hall. 